\title{
Isolation of novel coregulatory protein networks associated with DNA-bound estrogen receptor alpha Jennifer R Schultz-Norton ${ }^{1}$, Yvonne S Ziegler ${ }^{1}$, Varsha S Likhite ${ }^{2}$, John R Yates ${ }^{3}$ and Ann M Nardulli*1
}

Address: ${ }^{1}$ Department of Molecular and Integrative Physiology, University of Illinois at Urbana-Champaign, Urbana, IL 61801, USA, ${ }^{2}$ Department of Biochemistry, University of Illinois at Urbana-Champaign, Urbana, IL 61801, USA and ${ }^{3}$ Department of Cell Biology, The Scripps Institute, LaJolla, California 92037, USA

Email: Jennifer R Schultz-Norton - jschultznorton@mail.millikin.edu; Yvonne S Ziegler - yziegler@uiuc.edu;

Varsha S Likhite - varsha.likhite@gmail.com; John R Yates - jyates@scripps.edu; Ann M Nardulli* - anardull@life.uiuc.edu

* Corresponding author

Published: 30 October 2008

BMC Molecular Biology 2008, 9:97 doi:10.1 186/I47|-2199-9-97
Received: 6 August 2008

Accepted: 30 October 2008

This article is available from: http://www.biomedcentral.com/I47I-2199/9/97

(c) 2008 Schultz-Norton et al; licensee BioMed Central Ltd.

This is an Open Access article distributed under the terms of the Creative Commons Attribution License (http://creativecommons.org/licenses/by/2.0), which permits unrestricted use, distribution, and reproduction in any medium, provided the original work is properly cited.

\begin{abstract}
Background: DNA-bound transcription factors recruit an array of coregulatory proteins that influence gene expression. We previously demonstrated that DNA functions as an allosteric modulator of estrogen receptor $\alpha(E R \alpha)$ conformation, alters the recruitment of regulatory proteins, and influences estrogen-responsive gene expression and reasoned that it would be useful to develop a method of isolating proteins associated with the DNA-bound ER $\alpha$ using full-length receptor and endogenously-expressed nuclear proteins.
\end{abstract}

Results: We have developed a novel approach to isolate large complexes of proteins associated with the DNA-bound ER $\alpha$. Purified ER $\alpha$ and HeLa nuclear extracts were combined with oligos containing ER $\alpha$ binding sites and fractionated on agarose gels. The protein-DNA complexes were isolated and mass spectrometry analysis was used to identify proteins associated with the DNAbound receptor. Rather than simply identifying individual proteins that interact with ER $\alpha$, we identified interconnected networks of proteins with a variety of enzymatic and catalytic activities that interact not only with $E R \alpha$, but also with each other. Characterization of a number of these proteins has demonstrated that, in addition to their previously identified functions, they also influence ER $\alpha$ activity and expression of estrogen-responsive genes.

Conclusion: The agarose gel fractionation method we have developed would be useful in identifying proteins that interact with DNA-bound transcription factors and should be easily adapted for use with a variety of cultured cell lines, DNA sequences, and transcription factors.

\section{Background}

Estrogen receptor $\alpha(E R \alpha)$ is a ligand-inducible transcription factor involved in regulating expression of estrogenresponsive genes [1]. Upon binding hormone, ER $\alpha$ undergoes a conformational change, binds to estrogen response elements (EREs) residing in target genes, and initiates changes in gene expression. We and others have demonstrated that, in addition to the hormone-induced change in ER $\alpha$ conformation, the receptor undergoes another conformational change, which is induced by binding of 
the receptor to individual ERE sequences [2-7]. Thus, both hormone and DNA induce conformational changes in ER $\alpha$ structure.

$\mathrm{ER} \alpha$ does not function in isolation, but serves as a nucleating factor to recruit numerous coregulatory proteins required to effectively modulate transcription. In fact, much of what we know about regulation of estrogenresponsive genes has come through the identification of ERa-associated coregulatory proteins and elucidation of mechanisms by which they influence ER $\alpha$-mediated transactivation. The majority of ER $\alpha$-associated coregulatory proteins have been identified through their interaction with a discrete functional domain of the receptor, most commonly the ligand binding domain (Reviewed in $[8,9]$. The p160 proteins steroid receptor coactivator 1 (SRC-1), transcription intermediary factor 2 (TIF-2), and amplified in breast cancer 1 (AIB1) interact with ER $\alpha$ in a hormone-dependent manner and enhance ER $\alpha$-mediated transcription [10-17]. Both SRC-1 and AIB1 as well as CREB binding protein (CBP) and p300/CBP-associated factor ( $\mathrm{pCAF}$ ) possess intrinsic histone acetyltransferase activity that has been implicated in enhancing gene expression by modifying chromatin structure [18-24]. A large complex of proteins identified on the basis of its interaction with the thyroid hormone and vitamin $\mathrm{D}$ receptors has been designated as the thyroid hormone receptor associated protein (TRAP) or vitamin D receptor interacting protein (DRIP) complex [25-27]. DRIP205/ TRAP 220, which anchors the DRIP/TRAP complex to nuclear receptors, interacts with ER $\alpha$ in a ligand-dependent manner and enhances transcription $[28,29]$. In addition to the numerous coactivators that enhance ER $\alpha$ mediated transcription, the corepressors nuclear receptor corepressor (NCoR) and silencing mediator for RXR and TR (SMRT) bind to the antiestrogen-occupied receptor and inhibit ER $\alpha$-mediated transcription by recruiting protein complexes containing Sin 3 and histone deacetylases [30-34]. Thus, ER $\alpha$-associated coregulatory proteins have positive and negative effects on the ability of the receptor to activate transcription.

To better understand how ER $\alpha$ regulates transcription of estrogen-responsive genes, we developed a novel method to isolate proteins associated with the DNA-bound receptor, which utilizes full-length ER $\alpha$ and endogenouslyexpressed nuclear proteins and takes into account DNAand ligand-induced changes in receptor conformation. This method should be useful in isolating regulatory proteins associated with other DNA-bound transcription factors and could yield important new information about mechanisms regulating gene expression.

\section{Results \\ Characterization of protein-ER $\alpha$-ERE complexes}

To isolate novel proteins that associate with $E R \alpha$ and might influence estrogen-responsive gene expression, we developed a method that relied on the segregation of proteins on agarose gels and was based on the capacity of these proteins to associate with the ERE-bound receptor. Using this method, we were able to take into consideration DNA-induced modulation of ER $\alpha$ conformation, which we have demonstrated alters recruitment of coregulatory proteins to the DNA-bound receptor [2-5]. $\mathrm{E}_{2}$ was also included to ensure that ligand-induced changes in receptor conformation were considered.

As seen in Fig. 1, when radiolabeled, ERE-containing oligos were fractionated on an agarose gel, neither ER $\alpha$ (lane 2) nor HeLa nuclear extracts (lane 3 ) alone produced a discrete protein-DNA complex, but when both ER $\alpha$ and HeLa nuclear extracts were included, a distinct, higher order protein-DNA complex was present (lane 4). The ability of an ER $\alpha$-specific antibody (lane 6), but not a nonspecific antibody (lane 5), to supershift the proteinDNA complex indicated that the receptor was present in the complex and that interaction of the ER $\alpha$ antibody with the complex was specific. Furthermore, the ability of unlabeled ERE-containing oligos (lane 8), but not oligos containing a nonspecific DNA sequence (lane 7) to compete with the radiolabeled ERE-containing oligos confirmed the specificity of the receptor-DNA interaction. As an additional control, we utilized radiolabeled oligos that contained a nonspecific DNA sequence. While a proteinDNA complex was formed with the ERE-containing oligos, no complex was observed with the oligos containing a nonspecific DNA sequence (data not shown). Thus, this agarose-based gel fractionation method allowed us to isolate proteins that were ER $\alpha$ and ERE specific.

\section{Large scale isolation of protein-ER $\alpha$-ERE complexes}

Once we defined the gel conditions required for formation of specific protein-ER $\alpha$-ERE complexes, the next step was to increase the sample size so that sufficient amounts of protein would be available for isolation and identification. For these large-scale reactions, ER $\alpha$-specific antibody was utilized to stabilize the protein-ER $\alpha$-ERE complex and unlabeled oligos were used to avoid unintentional exposure of equipment to radioactive probe during the subsequent isolation and identification steps. However, smallscale samples containing radiolabeled oligos, purified $\mathrm{ER} \alpha, \mathrm{HeLa}$ nuclear extracts, and an ER $\alpha$-specific antibody were run in adjacent lanes so that the position of the protein-ER $\alpha$-ERE complexes in the gel could be determined (Fig. 2A, lanes 1 and 4).

Large-scale binding reactions containing unlabeled EREcontaining oligos, HeLa nuclear extracts, ER $\alpha$, and an 


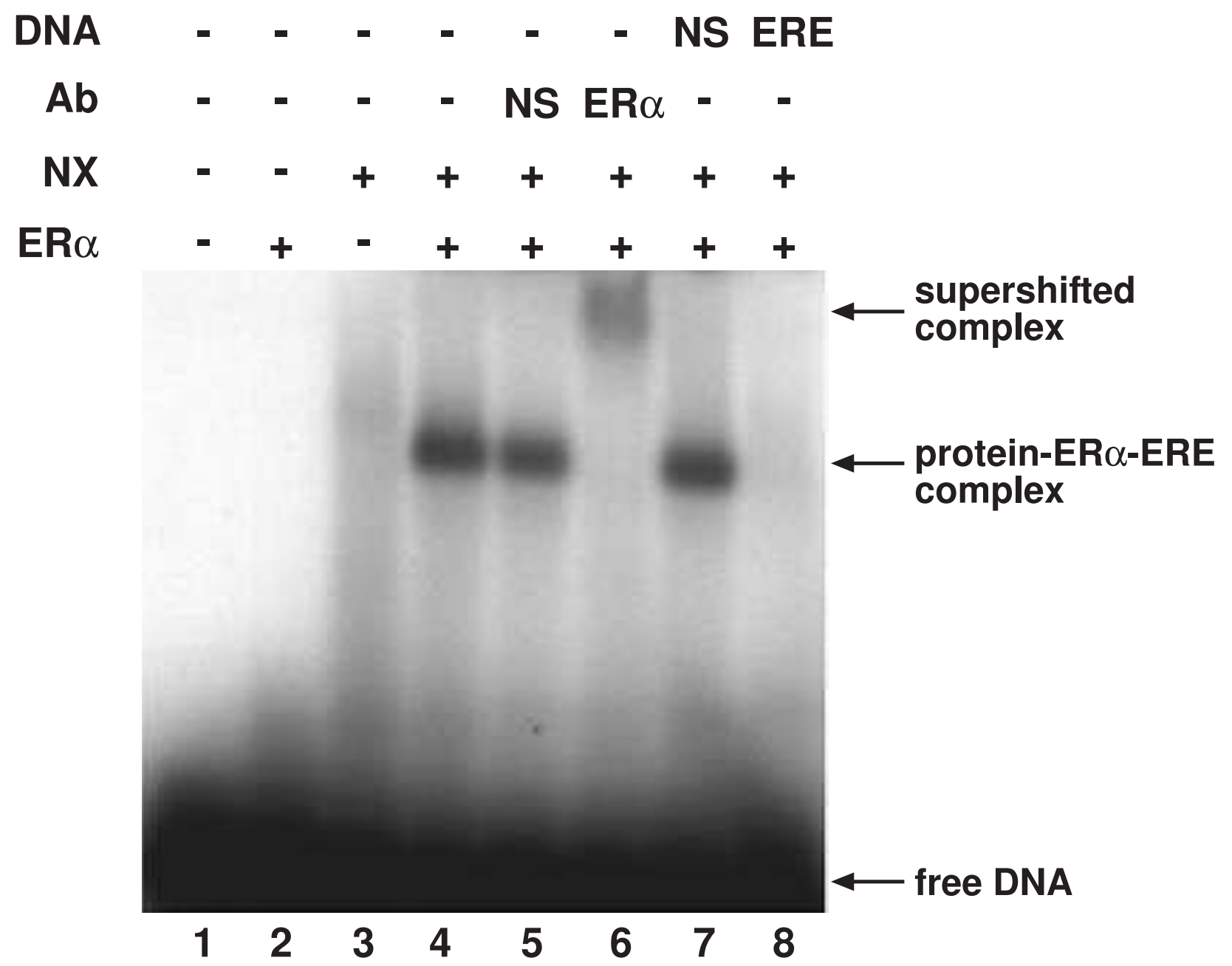

Figure I

Small-scale agarose gel electrophoresis. ${ }^{32}$ P-labeled, ERE-containing oligos were incubated without (lane I) or with ER $\alpha$ (lanes 2, 4-8) and/or HeLa nuclear extracts (NX, lanes 3-8). Nonspecific (NS) antibody (lane 5), ER $\alpha$-specific antibody (lane 6), unlabeled oligos containing a nonspecific (NS) DNA sequence (lane 7), or unlabeled ERE-containing oligos (lane 8) were added to the binding reactions to confirm that the complexes formed were specific. I7 $\beta$-estradiol $\left(E_{2}\right)$ was included in all binding reactions. Complexes were resolved on an agarose gel and visualized by autoradiography.

ER $\alpha$-specific antibody were fractionated on one preparative-sized lane of an agarose gel and the gel region comigrating with the radiolabeled complexes was excised (lane 3 , boxed area). Although distinct complexes were detected in our agarose gels when ER $\alpha$, HeLa nuclear extracts, and ER $\alpha$-specific antibody were included in the binding reactions (lanes 1 and 4), it seemed possible that some proteins might comigrate with the protein-ER $\alpha$-ERE complex, but not actually be associated with it. Thus, a large-scale binding reaction containing the unlabeled ERE-containing oligos, HeLa nuclear extracts, and ER $\alpha$-specific antibody, but no $E R \alpha$, was processed in parallel and served as a negative control. The gel region comigrating with the radiolabeled protein-ER $\alpha$-ERE complexes was also excised (lane 2, boxed area).

Initially, acetone or isopropanol precipitation was utilized to concentrate the proteins eluted from the agarose gel slices (data not shown). However, we found this method was unacceptable since it did not efficiently precipitate some proteins including ER $\alpha$. By using a nebulizer column, which pulverizes the gel matrix and extracts the liquid and proteins, the protein recovery was far more efficient. 


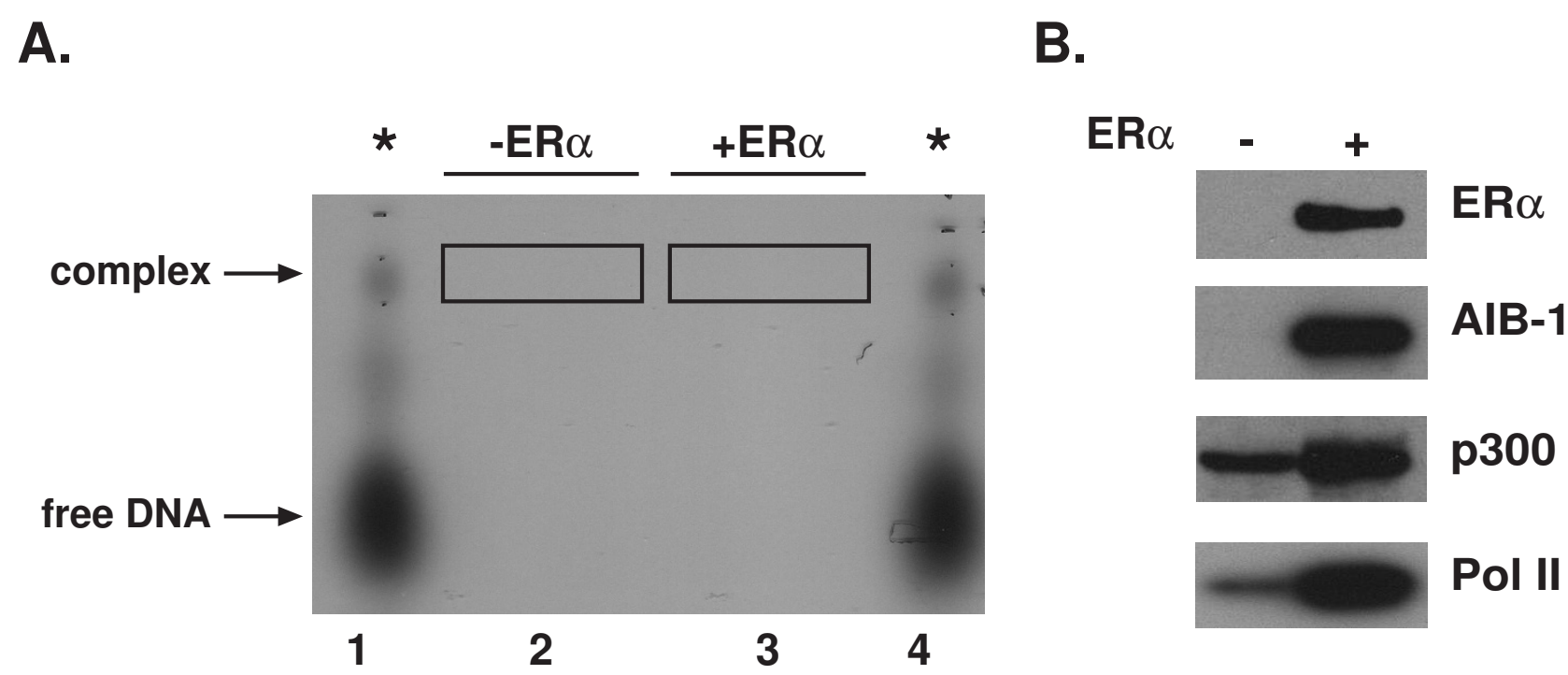

\section{Figure 2}

Large-scale agarose gel electrophoresis and complex analysis. A. Large-scale reactions containing unlabeled ERE-containing oligos were incubated with HeLa nuclear extracts and an ER $\alpha$-specific antibody in the absence (lane 2) or presence (lane 3) of purified ER $\alpha$. Small-scale reactions containing ${ }^{32} \mathrm{P}$-labeled ERE-containing oligos, HeLa nuclear extracts, an ER $\alpha$-specific antibody, and purified $E R \alpha$ were also prepared and run in parallel to indicate the location of the protein-DNA complexes (*, lanes $I$ and 4). $E_{2}$ was included in all binding reactions. Complexes were resolved on an agarose gel and were visualized in the wet gel by autoradiography. Gel regions comigrating with the 32P-labeled protein-ER $\alpha$-ERE complexes were excised (boxed areas) and contained unlabeled DNA and associated proteins without (lane 2) or with (lane 3) ER $\alpha$ and ER $\alpha$-specific antibody. B. Proteins were isolated from the excised agarose gel pieces and subjected to Western blot analysis with antibodies directed against ER $\alpha$, AIB-I, p300, or Pol II.

\section{Identification of known coregulatory proteins in the protein-DNA complexes}

To determine whether previously identified coregulatory proteins were associated with the ER $\alpha$-ERE complex or merely comigrated with it, Western analysis was carried out. As expected, ER $\alpha$ was detected when the purified receptor was included in the binding reaction with HeLa nuclear extracts, but not when it was omitted (Fig. 2B). AIB-1, a known p160 coactivator of ER $\alpha$-mediated transcription [12], was present in the complex when ER $\alpha$ had been added to the binding reaction, but not when it was omitted. Although p300 and RNA polymerase II (Pol II, Refs. [35-37] were detected in the absence of the receptor, significantly more p300 and Pol II were detected when $\mathrm{ER} \alpha$ had been included in the reaction. Thus, the complexes we isolated were comprised of ER $\alpha$ and transcription factors that are known to be involved in regulating estrogen-responsive gene expression. Furthermore, the effective association of the coregulatory proteins with the complex was dependent upon the presence of ER $\alpha$.

\section{Identification of coregulatory proteins associated with the ERE-bound ER $\alpha$}

Although we had shown that previously identified coregulatory proteins were present in our protein-ER $\alpha$-ERE complexes, the objective in these experiments was to identify novel proteins associated with the ERE-bound ER $\alpha$. Mass spectrometry analysis was used to identify proteins present in gel regions that comigrate with the radiolabeled protein-ER $\alpha$-ERE complexes (Fig. 2A, boxed areas). Numerous proteins involved in DNA replication and repair, chromatin remodeling, protein folding/stabilization, protein degradation, translation initiation and elongation, apoptosis, oxidative stress response, and signal transduction were identified (Table 1 and Additional file $1)$. While some proteins were identified in the absence and in the presence of $E R \alpha$, significantly more peptides were recovered in the presence of ER $\alpha$, as was observed in Fig. 2B with p300 and Pol II, reflecting a higher abundance of these proteins. The fact that we identified the same proteins in two or more experiments (see Additional file 1) suggests that the methods we used were reproducible. However, the most important validation of this method has come through functional characterization of these proteins. At this point, we have characterized the 
Table I: Proteins associated with the DNA-bound ER $\alpha$

\begin{tabular}{|c|c|c|c|c|}
\hline Protein & \# of discrete peptides & $\begin{array}{c}\% \text { a.a. sequence } \\
\text { identified }\end{array}$ & $\begin{array}{c}\text { Effect on ER } \alpha \text {-mediated } \\
\text { transcription }\end{array}$ & References Cited \\
\hline $\begin{array}{l}\text { 3-methyladenine DNA } \\
\text { glycosylase (MPG) }\end{array}$ & 3 & 14 & Decrease & {$[40]$} \\
\hline $\begin{array}{l}\text { apurinic endonuclease-I } \\
\text { (APEI) }\end{array}$ & 3 & 18 & Gene specific & $\begin{array}{l}\text { Curtis and Nardulli, } \\
\text { Submitted }\end{array}$ \\
\hline flap endonuclease-I (FENI) & 3 & 13 & Gene specific & {$[42]$} \\
\hline $\begin{array}{l}\text { high mobility group protein- } \\
2 \text { (HMG-2) }\end{array}$ & 2 & 13 & Increase & {$[49,50,67]$} \\
\hline $\begin{array}{l}\text { nonmetastatic protein } 23 \\
\text { homolog I (NM23-HI) }\end{array}$ & 5 & 35 & Decrease & {$[45]$} \\
\hline $\begin{array}{l}\text { proliferating cell nuclear } \\
\text { antigen (PCNA) }\end{array}$ & 9 & 57 & Increases basal & [43] \\
\hline $\begin{array}{l}\text { protein disulfide isomerase } \\
\text { (PDI) }\end{array}$ & 7 & 19 & Gene specific & {$[4 I]$} \\
\hline $\mathrm{Pp} 32$ & 5 & 19 & Decrease & [39] \\
\hline $\begin{array}{l}\text { retinoblastoma associated } \\
\text { protein } 46(\mathrm{RbAp} 46)\end{array}$ & 6 & 18 & Gene specific & [47] \\
\hline $\begin{array}{l}\text { retinoblastoma associated } \\
\text { protein } 48(\mathrm{RbAp} 48)\end{array}$ & 6 & 18 & Decrease & [47] \\
\hline $\begin{array}{l}\text { rho-GDP dissociation } \\
\text { inhibitor } \alpha(\text { RhoGDl } \alpha)\end{array}$ & 7 & 57 & Gene specific & [44] \\
\hline $\begin{array}{l}\text { superoxide dismutase I } \\
\text { (SODI) }\end{array}$ & 9 & 86 & Increase & {$[46]$} \\
\hline $\begin{array}{l}\text { template activating factor } I \beta \\
(\text { TAF-I } \beta \text { ) }\end{array}$ & 16 & 38 & Decrease & [38] \\
\hline thioredoxin (Trx) & 4 & 46 & Gene specific & $\begin{array}{l}\text { Rao and Nardulli, In } \\
\text { Preparation }\end{array}$ \\
\hline $\begin{array}{l}\text { thioredoxin reductase } \\
\text { (TrxR) }\end{array}$ & 14 & 54 & Gene specific & $\begin{array}{l}\text { Rao and Nardulli, In } \\
\text { Preparation }\end{array}$ \\
\hline
\end{tabular}

Selected ER $\alpha$-associated proteins were characterized. The effect of each protein on ER $\alpha$-mediated transcription was analyzed by transient transfection and/or RNA interference assays.

activity of 15 proteins associated with the DNA-bound $\mathrm{ER} \alpha$ (Table 1) and found that each of these proteins influences estrogen-responsive gene expression [38-47] and unpublished data).

\section{Isolation of protein-ER $\alpha$-ERE complexes using other cell lines}

The agarose gel fractionation method we developed is not restricted in the type of cells utilized. We have used this method to form large protein-DNA complexes with nuclear extracts from MCF-7 breast cancer cells, which express endogenous ER $\alpha$ (Fig. 3A). Inclusion of an ER $\alpha$ specific antibody supershifted the complex formed with these extracts. Interestingly, although we were unable to form a stable protein-ER $\alpha$-ERE complex with purified ER $\alpha$ and nuclear extracts from MDA-MB-231 human breast cancer cells, which do not express ER $\alpha$ (Fig. 3B), inclusion of an ER $\alpha$-specific antibody helped to stabilize proteinDNA complex formation. In fact, we routinely include ER $\alpha$-specific antibodies to help stabilize our protein-ER $\alpha$ ERE complexes.

\section{Discussion}

We have developed a method of isolating stable proteinDNA complexes, the formation of which requires $E R \alpha$, the ERE, and nuclear proteins. A number of factors were considered in establishing this methodology. First, full-length human ER $\alpha$ and endogenously-expressed nuclear proteins were utilized. Second, allosteric modulation of receptor conformation by DNA and hormone was taken into account by isolating proteins associated with the DNA-bound, $\mathrm{E}_{2}$-occupied ER $\alpha$. It is, after all, the estrogenoccupied, DNA-bound receptor that recruits coregulatory proteins and initiates changes in transcription. By considering both $\mathrm{E}_{2}$ - and DNA-induced changes in receptor conformation, we were able to identify proteins that are involved in transcriptional control and gain new insight to help define how changes in gene expression occur. Third, because traditional polyacrylamide gel shift assays do not allow large protein-DNA complexes to enter the gel [38,39,41-43,48-50], agarose gels were employed to isolate large molecular weight complexes containing $\mathrm{ER} \alpha$, ERE-containing oligos, and nuclear coregulatory proteins. In addition, low ionic strength buffer and ER $\alpha$-specific antibody were used to stabilize protein-ER $\alpha$-ERE com- 


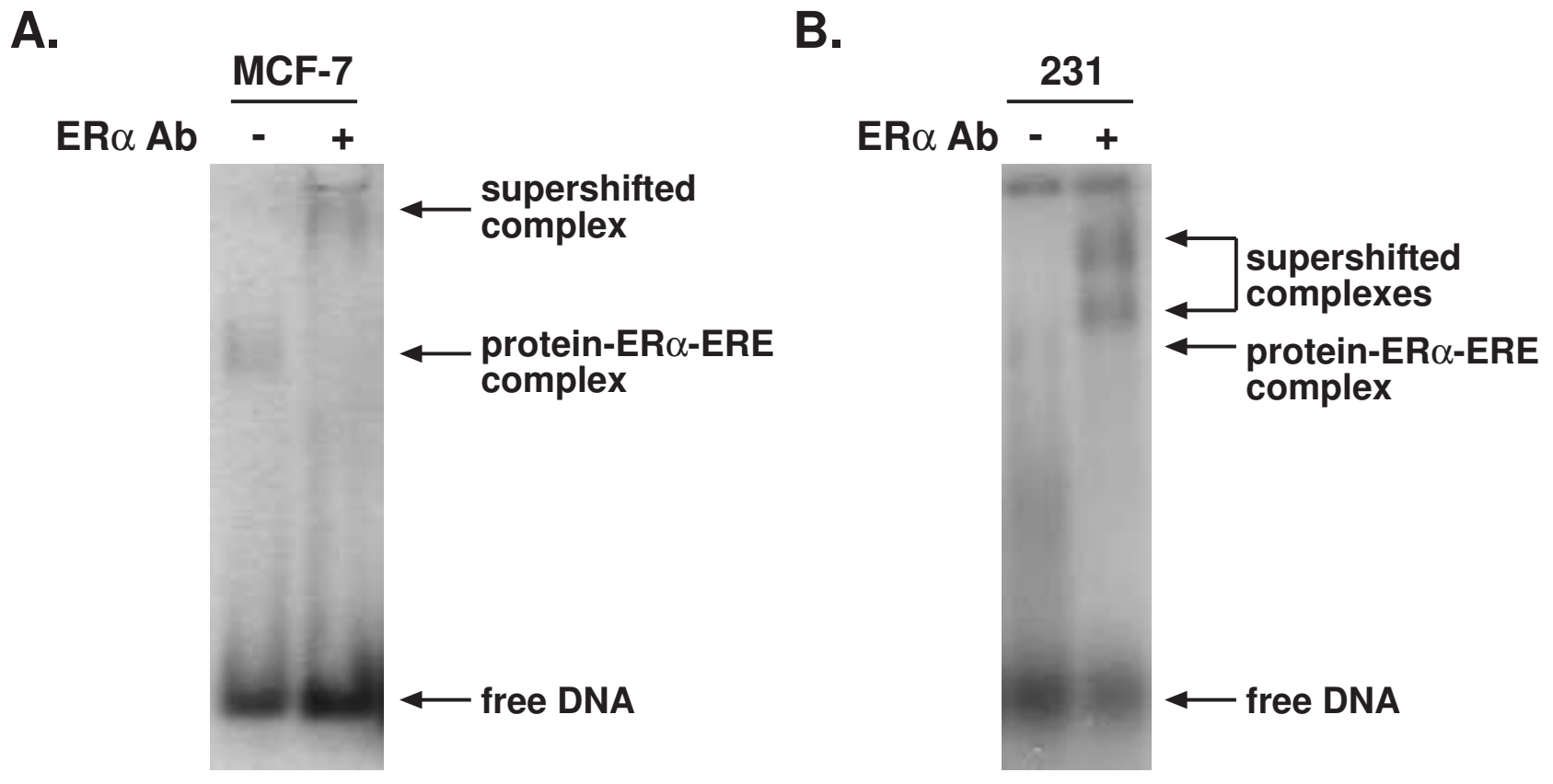

Figure 3

Small-scale agarose gel electrophoresis using MCF-7 and MDA-MB-23 I nuclear extracts. ${ }^{32} \mathrm{P}-\mathrm{labeled}$ ERE-containing oligos were incubated with nuclear extracts from MCF-7 breast cancer cells, which endogenously express ER $\alpha$ (A), or nuclear extracts from MDA-MB-23I breast cancer cells and purified ER $\alpha$ (B). An ER $\alpha$-specific antibody was included in the binding reaction as indicated. Complexes were resolved on agarose gels and visualized by autoradiography.

plexes during the extended period of electrophoresis required. Finally, a nebulizer spin column utilized for isolating proteins from the agarose gel significantly raised the signal to noise ratio and was critical in recovering $E R \alpha$ and its associated proteins.

The electrophoretic agarose gel fractionation method has distinct advantages over other methods we previously used to isolate ER $\alpha$-associated proteins. ER $\alpha$ pull-down assays were useful in identifying HeLa nuclear proteins associated with the flag-tagged ER $\alpha$, but the number of proteins identified using this method was limited [38,39]. DNA affinity assays, which we used to identify a DNA glycosylase that associates with the ERE-bound ER $\alpha$ [40], were limited by the fact that numerous nuclear proteins bound to the ERE-containing oligos and/or agarose beads in the absence of ER $\alpha$ and produced a background that made it difficult to distinguish specific from nonspecific proteins. The agarose gel fractionation method allowed us to isolate a suite of ER $\alpha$-associated proteins and significantly decreased the proportion of nonspecifically-bound proteins.

\section{Isolation of interconnected protein networks}

At first glance, it might appear that much of what we have done has been to identify a number of individual proteins that interact with $\mathrm{ER} \alpha$ and influence estrogen-responsive gene expression. However, one of the most fascinating findings from our agarose gel-based approach was that rather than simply identifying individual proteins that interact with ERa, we identified interconnected networks of proteins with a variety of enzymatic and catalytic activities that interact not only with ER $\alpha$, but also with each other (Table 2).

Two examples of the ER $\alpha$-associated protein networks we isolated are illustrated in Fig. 4. We identified four proteins involved in DNA repair, 3-methyladenine DNA glycosylase (MPG), apurinic endonuclease 1 (APE1), proliferating cell nuclear antigen (PCNA), and flap endonuclease, (FEN1), each of which was associated with the DNA-bound ER $\alpha$ and influences estrogen-responsive gene expression (Refs. [40,42,43] and C. Curtis and A. Nardulli, unpublished data) These proteins form an interactive complex of proteins (Fig. 4A and Table 2) that together are involved in base excision repair (BER). Another complex of proteins we isolated were previously identified as the SET or INHAT complex [51-53], which is 
Table 2: ER $\alpha$-associated protein interactions

\begin{tabular}{|c|c|c|}
\hline Protein & Interacting Protein & Reference(s) \\
\hline \multirow[t]{7}{*}{ APEI } & $\mathrm{ER} \alpha$ & Curtis and Nardulli, Submitted \\
\hline & FENI & {$[68]$} \\
\hline & HMG-2 & {$[61,69]$} \\
\hline & NM23-HI & {$[6 I]$} \\
\hline & PCNA & {$[68,70]$} \\
\hline & pp32 & [6I] \\
\hline & TAF-I $\beta$ & [61] \\
\hline \multirow[t]{3}{*}{ FENI } & APEI & {$[68]$} \\
\hline & $\mathrm{ER} \alpha$ & {$[42]$} \\
\hline & PCNA & {$[67,71-74]$} \\
\hline \multirow[t]{5}{*}{ HMG-2 } & APEI & {$[61,69]$} \\
\hline & $\mathrm{ER} \alpha$ & {$[49,75]$} \\
\hline & NM23-HI & [61] \\
\hline & pp32 & {$[61]$} \\
\hline & TAF-I $\beta$ & {$[61,69]$} \\
\hline \multirow[t]{2}{*}{ MPG } & $\mathrm{ER} \alpha$ & {$[40]$} \\
\hline & PCNA & [70] \\
\hline \multirow[t]{5}{*}{ NM23-HI } & APEI & {$[61]$} \\
\hline & $\mathrm{ER} \alpha$ & {$[45]$} \\
\hline & HMG-2 & {$[61]$} \\
\hline & $\mathrm{pp} 32$ & [6I] \\
\hline & TAF-I $\beta$ & {$[60]$} \\
\hline \multirow[t]{6}{*}{ pp32 } & APEI & {$[61]$} \\
\hline & $\mathrm{ER} \alpha$ & [39] \\
\hline & HMG-2 & {$[61]$} \\
\hline & NM23-HI & {$[61]$} \\
\hline & PCNA & [76] \\
\hline & TAF-I $\beta$ & {$[51-53,59,60]$} \\
\hline \multirow[t]{6}{*}{ PCNA } & APEI & {$[68,70]$} \\
\hline & $\mathrm{ER} \alpha$ & {$[43]$} \\
\hline & FENI & {$[67,71-74]$} \\
\hline & MPG & [70] \\
\hline & pp32 & [76] \\
\hline & TAF-I $\beta$ & [76] \\
\hline \multirow[t]{6}{*}{ TAF-I $\beta$} & APEI & {$[61]$} \\
\hline & $\mathrm{ER} \alpha$ & [38] \\
\hline & HMG-2 & {$[61,69]$} \\
\hline & NM23-HI & {$[60]$} \\
\hline & Pp32 & {$[5 \mathrm{I}-53,59,6 \mathrm{I}]$} \\
\hline & PCNA & {$[76]$} \\
\hline
\end{tabular}

comprised of template activating factor I $\beta$ (TAF-I $\beta)$, pp32, high mobility group protein 2 (HMG-2), APE1, and nonmetastatic protein homolog $1(\mathrm{NM} 23-\mathrm{H} 1)$. These proteins form an interactive group involved in determining cell fate by initiating DNA repair or caspase-independent apoptosis (Fig. 4B and Table 2, Refs. [54,55]. Interestingly, we have characterized the effects of each of these proteins on ER $\alpha$ activity and found that each of these proteins influences expression of estrogen-responsive genes [38$40,42,43,45]$ and unpublished data).

The ER $\alpha$-associated proteins we isolated are each endowed with specific activities that collectively alter basic cellular processes. As shown in Fig. 5, the DNA glycosylase MPG catalyzes the removal of a damaged or modified base and the formation of an apurinic site [56,57]. APE1 recognizes this apurinic site and initiates strand incision. DNA repair is then completed by polymeraseinduced insertion of a single nucleotide and ligation. This process of replacing a single base is referred to as short patch BER. Alternatively, the DNA can be repaired through long patch BER in which FEN1 removes a short flap of nucleotides. PCNA serves as a platform for FEN1, stabilizes the interaction of FEN1 with the DNA flap, and enhances FEN1 cleavage efficiency [58]. The interaction of these DNA repair proteins with ERa is both physical and functional, but more importantly, their identification led to the discovery of an integrated protein network associated with the DNA-bound receptor that is involved in DNA repair (Figs. $4 \mathrm{~A}$ and 5 and Table 2).

The SET complex is likewise comprised of an interactive group of proteins involved in regulating cellular processes, which has been described in detail by Lieberman and coworkers [52,54,59-61]. In normal cells, NM23-H1 assists in maintaining DNA integrity by nicking DNA and initiating DNA repair. In these cells, NM23-H1's DNase I activity is limited by its inhibitor, TAF-I $\beta$. However, a different scenario ensues when cytotoxic $\mathrm{T}$ lymphocytes detect a virally infected or tumor cell. In this instance, the cytotoxic T lymphocytes release Granzyme A, which enters the target cell and cleaves the inhibitor of NM23-H1, TAFI $\beta$, as well as HMG-2 and APE1 (Fig. 6). With its inhibitor destroyed, NM23H1-induced DNA nicking is increased and caspase-independent apoptosis is initiated. The destruction of APE1 in these cells further hobbles the DNA repair machinery and helps to ensure that the cells undergo apoptosis. We isolated all of the SET complex proteins (pp32, TAF-I $\beta$, NM23-H1, HMG-2, and APE1) in our protein-DNA complexes. We and others showed previously that HMG proteins interact with ERa and other nuclear receptors, enhance receptor-DNA interaction, and increase receptor-mediated transactivation [50,62-64].

We are intrigued by the fact that the proteins we isolated interact with ER $\alpha$ and with each other (Fig. 4 and Table 2) providing evidence that these proteins belong to interactive networks of proteins with discrete cellular functions. The interaction of the protein networks may be fostered by the association of a protein with more than one network. For example, APE1, which interacts with ER $\alpha$, components of long- and short-patch BER complexes, and SET complex proteins, may help to coordinate the actions of 


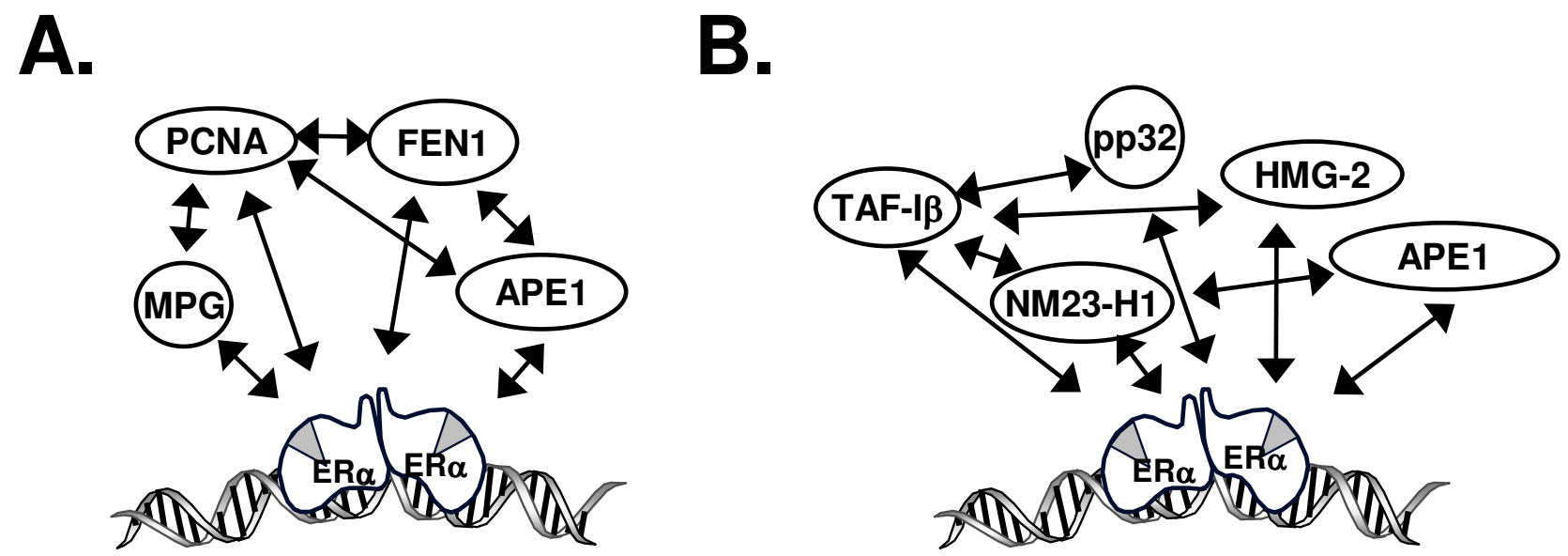

\section{Figure 4}

ER $\alpha$-associated proteins form interconnected networks. A. Interactions between ER $\alpha$ and the DNA repair proteins MPG, PCNA, FENI, and APEI. B. Interactions between ER $\alpha$ and the SET complex proteins TAF-I $\beta$, PP32, NM23-HI, HMG-2, and APEI.

these protein networks and link DNA repair and transcription.

The interaction of ER $\alpha$ with its associated proteins may not only be physical, but may have functional consequences for both proteins. We know that MPG influences ER $\alpha$-mediated transactivation and that, in turn, ER $\alpha$ enhances the association of MPG with modified DNA and promotes base excision [65]. Thus, by recruiting protein complexes involved in DNA repair, ER $\alpha$ may help to preferentially maintain the integrity of transcriptionallyactive, estrogen-responsive genes.

Taken together, our findings suggest that the ERE-bound ER $\alpha$ serves as a nucleating factor to recruit a cohort of proteins with a variety of cellular functions that influence estrogen-responsive gene expression and that $\mathrm{ER} \alpha$ may in

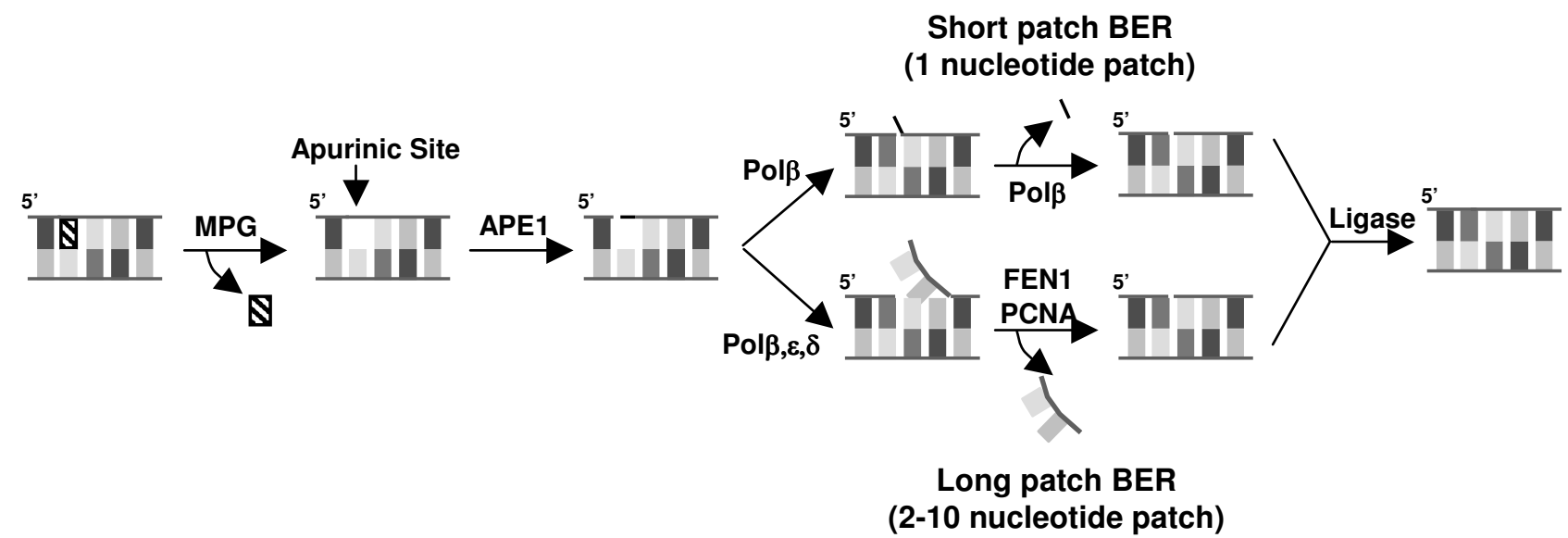

Figure 5

ER $\alpha$-associated proteins are involved in base excision repair. MPG, PCNA, FENI, and APEI form an interconnected network of proteins involved in short- and long-patch BER. 


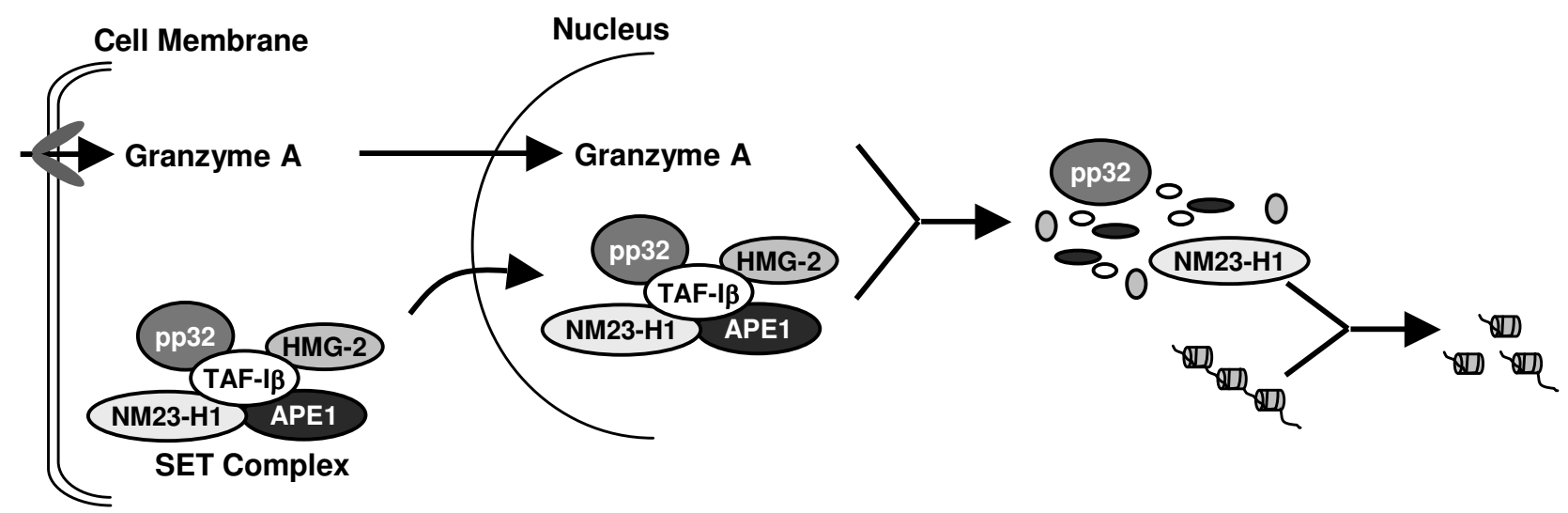

Figure 6

ER $\alpha$-associated proteins are in the SET complex. TAF-I $\beta$, pp32, HMG-2, NM23-HI, and APEI form an interconnected network of proteins involved in DNA repair and/or apoptosis. (Adapted from Refs. [54,55].

turn enhance DNA repair and ultimately help to determine cell fate.

\section{Conclusion}

The electrophoretic agarose fractionation protocol that we have developed provides a method to isolate interrelated networks of ER $\alpha$-associated proteins involved in regulating estrogen-responsive gene expression. These studies have provided a fascinating glimpse of the complexity involved in regulating estrogen-responsive genes. This agarose gel fractionation method should be readily adaptable to a variety of cultured cell lines, DNA sequences, and transcription factors and help to define how proteins associated with DNA-bound transcription factors influence gene expression and other critical cellular processes.

\section{Methods \\ Small scale characterization of protein-DNA complex formation}

HeLa nuclear extracts and baculovirus-expressed, purified ER $\alpha$ were prepared as previously described [3,66]. Oligos containing the Xenopus laevis vitellogenin A2 estrogen response element flanked by the native DNA sequence (ERE, (5'-GAT TAA CTG TCC AAA GTC AGG TCA CAG TGA CCT GAT CAA AGT TAA TGT AA-3' and 5'-TTA CAT TAA CTT TGA TCA GGT CAC TGT GAC CTG ACT TTG GAC AGT TAA TC-3') were annealed and end labeled with ${ }^{32} \gamma \mathrm{P}$-ATP. Radiolabeled oligos (10 pmol) were incubated with 400 fmol purified ER $\alpha$ in binding buffer $(15 \mathrm{mM}$ Tris, $0.2 \mathrm{mM}$ EDTA, $80 \mathrm{mM} \mathrm{KCl}, 50 \mu \mathrm{M} \mathrm{ZnCl}, 5 \mathrm{mM}$ MgOAc, $10 \%$ glycerol, $4 \mathrm{mM}$ DTT) with $1 \mu \mathrm{g}$ of poly dI/ $\mathrm{dC}, 1 \mu \mathrm{g}$ salmon sperm DNA, $1 \mu \mathrm{g}$ BSA, and $10 \mu \mathrm{M} 17 \beta$ estradiol (E2) for ten minutes at room temperature. HeLa nuclear extracts $(10 \mu \mathrm{g})$ were then added and incubated at room temperature for an additional 20 minutes. Reac- tions lacking ER $\alpha$ were run in parallel with additional BSA added to maintain constant protein concentrations. 200 ng of antibody directed against YY1 (control antibody) or ER $\alpha$ (sc-7341 or sc-8005, Santa Cruz Biotechnology, Santa Cruz, CA) or 10 pmol of unlabeled double-stranded oligos containing an ERE or nonspecific DNA sequence (NS, 5'-CTA GAT TAC TTC TCA TGT TAG ACA TAC TCA3', and 5'GAT CTG AGT ATG TCT AAC ATG AGA AGT AAT CTA G-3') were included in the binding reactions as indicated. The complexes and the free DNA were separated on a horizontal $1.25 \%$ low melt agarose gel (BioRad, Hercules, CA $)$ in a modified TBE buffer $(0.45 \mathrm{mM}$ Tris $\mathrm{pH} 7.9$, $4.5 \mathrm{mM}$ boric acid, $2 \mathrm{mM}$ EDTA) containing $5 \mathrm{mM}$ $\mathrm{MgOAc}$ at 100 volts for two hours at $4^{\circ} \mathrm{C}$. The gel was dried on DE81 ion exchange cellulose acetate (Whatman, Florham Park, NJ) at $65 \mathrm{C}$ for 30 minutes under vacuum and visualized by autoradiography.

\section{Large scale complex formation}

For large scale isolation of protein-ER $\alpha$-ERE complexes, DNA oligos containing the Xenopus laevis A2 ERE and surrounding DNA sequence were annealed and the binding reactions were incubated as described above except that they were increased to include 50 pmol DNA, $260 \mu \mathrm{g}$ of HeLa nuclear extract with or without $18 \mathrm{pmol}$ of $\mathrm{ER} \alpha$ in a total volume of $200 \mu \mathrm{l}$. $3.2 \mu \mathrm{g}$ of an ER $\alpha$-specific antibody (sc-8002, Santa Cruz Biotechnology, Santa Cruz, CA) was added to help stabilize the ER $\alpha$-containing complexes. All samples were loaded onto $10 \mathrm{~cm} \times 15 \mathrm{~cm}$ horizontal $1.25 \%$ agarose gels prepared with molecular biology grade agarose (BioRad, Hercules, CA) and modified TBE buffer. Unlabeled ERE-containing oligos were utilized in all samples submitted for mass spectrometry analysis. Marker lanes, which contained radiolabeled oligos, 3 pmol ER $\alpha, 50 \mu \mathrm{g}$ HeLa nuclear extract, and $0.6 \mu \mathrm{g}$ of ER $\alpha$ - 
specific antibody in $40 \mu \mathrm{l}$ total volumes were run in parallel at $100 \mathrm{~V}$ for $2 \mathrm{~h}$ to indicate the position of the complexes. After fractionation, the wet gel was subjected to autoradiography overnight at room temperature and the regions containing the unlabeled protein-ER $\alpha$-ERE complexes were excised. Proteins were isolated with the Montage gel extraction kit (Millipore, Billerica, MA) according to manufacturer's directions. The extracted proteins were concentrated using Microcon YM-10 size exclusion columns (Millipore, Billerica, MA) with a molecular weight cutoff of $10 \mathrm{kDa}$ and then subjected to mass spectrometry analysis as previously described [38]. Peptide fragments found in multiple proteins were excluded from the data analysis.

\section{Western analysis of ER $\alpha$-associated proteins}

Proteins isolated from large-scale agarose gels were fractionated on denaturing SDS-PAGE, transferred to nitrocellulose, and subjected to Western analysis. Blots were probed with antibodies specific to ER $\alpha$, p300, RNA polymerase II (sc-8005, sc-585, or sc-899, respectively, Santa Cruz Biotechnologies, Santa Cruz, CA) or AIB-1 (A79920, BD Transduction Labs) and a horseradish peroxidase-conjugated secondary antibody. Proteins were visualized using a chemiluminescent detection system as previously described [4].

\section{Abbreviations}

ER $\alpha$ : estrogen receptor $\alpha$; ERE: estrogen response element; NCoR: nuclear receptor corepressor; SMRT: silencing mediator for RXR and TR; TIF-2: transcription intermediary factor 2; AIB1: amplified in breast cancer 1; Pol II: RNA polymerase II; MPG: 3-methyladenine DNA glycosylase; APE1: apurinic endonuclease 1; PCNA: proliferating cell nuclear antigen; FEN1: flap endonuclease 1; BER: base excision repair; TAF-I $\beta$ : template activating factor $\mathrm{I} \beta$; HMG-2: high mobility group protein 2; NM23-H1: nonmetastatic protein 23 homolog 1 .

\section{Authors' contributions}

VSL developed the initial approach of isolating proteinreceptor-DNA complexes using agarose gel fractionation. The method was further refined by JRS-N and then by YSZ, who isolated the majority of the proteins identified. JRY and coworkers identified each of the receptor-associated proteins using mass spectrometry analysis and AMN guided the overall project. All authors have read and approved the final manuscript.

\section{Additional material}

\section{Additional file 1}

ER $\alpha$-interacting proteins isolated from agarose gel complexes. HeLa nuclear extracts were incubated with ER $\alpha$-specific antibody and radiolabeled ERE-containing oligos in the absence or presence of purified ER $\alpha$. Isolated proteins were subjected to trypsin digestion and mass spectrometry analysis. Peptide sequences were blasted against the SEQUEST database to identify the isolated proteins. Proteins identified in more than one independent experiment are grouped by cellular function and listed by gene name, accession number, and protein description. The number of independent experiments in which each protein was identified, the number of peptides isolated, and the percent of amino acid sequence identified are indicated. Data are compiled from 4 independent experiments.

Click here for file

[http://www.biomedcentral.com/content/supplementary/14712199-9-97-S1.xls]

\section{Acknowledgements}

We are grateful to members of the Yates laboratory, who identified the proteins isolated in our large-scale agarose gels. This work was supported by NIH grant ROI DK 53884 (to AMN) and NIH P4I RRI I 823-I0 (to JRY). JRS-N was supported by NIH Reproductive Biology T32 HD07028.

\section{References}

I. Beato M, Herrlich P, Schutz G: Steroid hormone receptors: many actors in search of a plot. Cell 1995, 83:85I-857.

2. Wood JR, Greene GL, Nardulli AM: Estrogen response elements function as allosteric modulators of estrogen receptor conformation. Mol Cell Biol 1998, 18:1927-1934.

3. Wood JR, Likhite VS, Loven MA, Nardulli AM: Allosteric modulation of estrogen receptor conformation by different estrogen response elements. Mol Endocrinol 200 I, I5: I I I4-I I 26.

4. Loven MA, Likhite VS, Choi I, Nardulli AM: Estrogen response elements alter coactivator recruitment through allosteric modulation of estrogen receptor beta conformation. J Biol Chem 200I, 276:45282-45288.

5. Loven MA, Wood JA, Nardulli AM: Interaction of estrogen receptors alpha and beta with estrogen response elements. Mol Cell Endocrinol 200I, 181:15I-163.

6. Klinge CM: Estrogen receptor interaction with estrogen response elements. Nucleic Acids Res 2001, 29:2905-2919.

7. Hall JM, McDonnell DP, Korach KS: Allosteric regulation of estrogen receptor structure, function, and coactivator recruitment by different estrogen response elements. Mol Endocrinol 2002, 16:469-486.

8. Robyr D, Wolffe AP, Wahli W: Nuclear hormone receptor coregulators in action: diversity for shared tasks. Mol Endocrinol 2000, 14:329-347.

9. Torchia J, Glass C, Rosenfeld MG: Co-activators and co-repressors in the integration of transcriptional responses. Curr Opin Cell Biol 1998, 10:373-383.

10. Halachmi S, Marden E, Martin G, MacKay H, Abbondanza C, Brown M: Estrogen receptor-associated proteins: possible mediators of hormone-induced transcription. Science 1994, 264: $1455-\mid 458$.

II. Oñate SA, Tsai SY, Tsai M-J, O'Malley BW: Sequence and characterization of a coactivator for the steroid hormone receptor superfamily. Science 1995, 270: I354-I357.

12. Anzick SL, Kononen J, Walker RL, Azorsa DO, Tanner MM, Guan X$Y$, Sauter G, Kallioniemi O-P, Trent JM, Meltzer PS: AIB I, a steroid receptor coactivator amplified in breast and ovarian cancer. Science 1997, 277:965-968.

13. Chen H, Lin RJ, Schiltz RL, Chakravarti D, Nash A, Nagy L, Privalsky ML, Nakatani Y, Evans RM: Nuclear receptor coactivator ACTR is a novel histone acetyltransferase and forms a multimeric 
activation complex with P/CAF and CBP/p300. Cell 1997, 90:569-580

14. Li H, Gomes PJ, Chen JD: RAC3, a steroid/nuclear receptorassociated coactivator that is related to SRC-I and TIF2. Proc Natl Acad Sci USA 1997, 94(16):8479-8484.

15. Voegel JJ, Heine MJS, Zechel C, Chambon P, Gronemeyer H: TIF 2, a I 60 kDa transcriptional mediator for the ligand-dependent activation function AF-2 of nuclear receptors. EMBO J 1996, 15: $101-108$.

16. Hong H, Kulwant K, Trivedi A, Johnson DL, Stallcup MR: GRIPI, a novel mouse protein that serves as a transcriptional coactivator in yeast for the hormone binding domains of steroid receptors. Proc Natl Acad Sci USA 1996, 93:4948-4952.

17. Hong H, Kohli K, Garabedian MJ, Stallcup MR: GRIPI, a transciptional coactivator for the AF-2 transactivation domain of steroid, thyroid, retinoid, and vitamin $D$ receptors. Mol Cell Biol 1997, 1 7:2735-2744.

18. Yang XJ, Ogryzko VV, Nishikawa J, Howard BH, Nakatani Y: A p300/ CBP-associated factor that competes with the adenoviral oncoprotein EIA. Nature 1996, 382(6589):319-324.

19. Ogryzko VV, Schiltz RL, Russanova V, Howard BH, Nakatani Y: The transcriptional coactivators $\mathrm{p} 300$ and CBP are histone acetyltransferases. Cell 1996, 87:953-959.

20. Spencer TE, Jenster G, Burcin MM, Allis CD, Zhou J, Mizzen CA, McKenna NJ, Onate SA, Tsai SY, Tsai M-J, O'Malley BW: Steroid receptor coactivator-I is a histone acetyltransferase. Nature 1997, 389:194-198.

21. Eckner R, Ewen ME, Newsome D, Gerdes M, Decaprio JA, Lawrence JB, Livingston DM: Molecular cloning and functional analysis of the adenovirus EIA-associated 300-kD protein (p300) reveals a protein with properties of a transcriptional adaptor. Genes Dev 1994, 8:869-884.

22. Smith CL, Oñate SA, Tsai M-J, O'Malley BW: CREB binding protein acts synergistically with steroid receptor coactivator-I to enhance steroid receptor-dependent transcription. Proc Natl Acad Sci USA 1996, 93:8884-8888.

23. Chakravarti D, LaMorte VJ, Nelson MC, Nakajima T, Schulman IG, Juguilon H, Montminy M, Evans RM: Role of CBP/P300 in nuclear receptor signaling. Nature 1996, 383:99-103.

24. Hanstein B, Liu H, Yancisin MC, Brown M: Functional analysis of a novel estrogen receptor beta isoform. Mol Endocrinol 1999, 13:129-137.

25. Fondell JD, Ge H, Roeder RG: Ligand induction of a transcriptionally active thyroid hormone receptor coactivator complex. Proc Natl Acad Sci USA 1996, 93( (16):8329-8333.

26. Rachez C, Suldan Z, Ward J, Chang CP, Burakov D, Erdjument-Bromage $\mathrm{H}$, Tempst $\mathrm{P}$, Freedman LP: A novel protein complex that interacts with the vitamin D3 receptor in a ligand-dependent manner and enhances VDR transactivation in a cell-free system. Genes Dev 1998, I 2( I 2): 1787-I800.

27. Rachez C, Lemon BD, Suldan Z, Bromleigh V, Gamble M, Naar AM, Erdjument-Bromage $H$, Tempst $P$, Freedman LP: Ligand-dependent transcription activation by nuclear receptors requires the DRIP complex. Nature 1999, 398(6730):824-828

28. Yuan CX, Ito M, Fondell JD, Fu ZY, Roeder RG: The TRAP220 component of a thyroid hormone receptor-associated protein (TRAP) coactivator complex interacts directly with nuclear receptors in a ligand-dependent fashion. Proc Natl Acad Sci USA 1998, 95( (14):7939-7944.

29. Burakov D, Wong CW, Rachez C, Cheskis BJ, Freedman LP: Functional interactions between the estrogen receptor and DRIP205, a subunit of the heteromeric DRIP coactivator complex. J Biol Chem 2000, 275(27):20928-20934.

30. Zamir I, Harding HP, Atkins GB, Horlein A, Glass CK, Rosenfeld MG, Lazar MA: A nuclear hormone receptor corepressor mediates transcriptional silencing by receptors with distinct repression domains. Mol Cell Biol 1996, 16:5458-5465.

31. Chen JD, Evans RM: A transcriptional co-repressor that interacts with nuclear hormone receptors. Nature 1995 377:454-457.

32. Smith C, Nawaz Z, O'Malley B: Coactivator and corepressor regulation of agonist/antagonist activity of the mixed antiestrogen, 4-hydroxytamoxifen. Mol Endocrinol 1997, I I:657-666.

33. Heinzel T, Lavinsky RM, Mullen TM, Soderstrom M, Laherty CD, Torchia J, Yang WM, Brard G, Ngo SD, Eisenman RN, Rose DW, Glass CK, Rosenfeld MG: A complex containing $\mathbf{N}-\mathrm{CoR}, \mathbf{m S i n} 3$ and histone deacetylase mediates transcriptional repression. Nature 1997, 386:43-48.

34. Nagy L, Kao H-Y, Chakravarti D, Lin RJ, Hassig CA, Ayer DE, Schreiber SL, Evans RM: Nuclear receptor repression mediated by a complex containing SMRT, $\mathrm{mSin} 3 \mathrm{~A}$, and histone deacetylase. Cell 1997, 89:373-380.

35. Hanstein B, Eckner R, DiRenzo J, Halachmi S, Liu H, Searcy B, Kurokawa $R$, Brown M: p300 is a component of an estrogen receptor coactivator complex. Proc Natl Acad Sci USA 1996, 93(2I): I I540-I I545.

36. Ranish JA, Yudkovsky N, Hahn S: Intermediates in formation and activity of the RNA polymerase II preinitiation complex: holoenzyme recruitment and a postrecruitment role for the TATA box and TFIIB. Genes Dev 1999, I3(I):49-63.

37. Soutoglou E, Talianidis I: Coordination of PIC assembly and chromatin remodeling during differentiation-induced gene activation. Science 2002, 295(556 I): 190I-1904.

38. Loven MA, Muster N, Yates JR, Nardulli AM: A novel estrogen receptor alpha associated protein, template activating factor I beta, inhibits acetylation and transactivation. Mol Endocrinol 2003, 17:67-78.

39. Loven MA, Davis RE, Curtis CD, Muster N, Yates JR, Nardulli AM: A novel estrogen receptor alpha-associated protein alters receptor-deoxyribonucleic acid interactions and represses receptor-mediated transcription. Mol Endocrinol 2004, I 8( I I ):2649-2659.

40. Likhite VS, Cass EI, Anderson SD, Yates JR, Nardulli AM: Interaction of estrogen receptor alpha with 3-methyladenine DNA glycosylase modulates transcription and DNA repair. J Biol Chem 2004, 279(16): 16875-16882.

4I. Schultz-Norton JR, McDonald WH, Yates JR, Nardulli AM: Protein disulfide isomerase serves as a molecular chaperone to maintain estrogen receptor alpha\} structure and function. Mol Endocrinol 2006, 20(9): 1982-1995.

42. Schultz-Norton JR, Walt KA, Ziegler YS, McLeod IX, Yates JR, Raetzman LT, Nardulli AM: The deoxyribonucleic acid repair protein flap endonuclease-I modulates estrogen-responsive gene expression. Mol Endocrinol 2007, 2I (7):1569-1580.

43. Schultz-Norton JR, Gabisi VA, Ziegler YS, McLeod IX, Yates JR, Nardulli AM: Interaction of estrogen receptor alpha with proliferating cell nuclear antigen. Nucleic Acids Res 2007, 35(I5):5028-5038.

44. El Marzouk S, Schultz-Norton JR, Likhite VS, McLeod IX, Yates JR, Nardulli AM: Rho GDP dissociation inhibitor alpha interacts with estrogen receptor alpha and influences estrogen responsiveness. J Mol Endocrinol 2007, 39(4):249-259.

45. Curtis CD, Likhite VS, McLeod IX, Yates JR, Nardulli AM: Interaction of the tumor metastasis suppressor nonmetastatic protein 23 homologue $\mathrm{HI}$ and estrogen receptor alpha alters estrogen-responsive gene expression. Cancer Res 2007, 67(21): 10600-10607.

46. Rao AK, Ziegler YS, McLeod IX, Yates JR, Nardulli AM: Effects of cu/ zn superoxide dismutase on estrogen responsiveness and oxidative stress in human breast cancer cells. Mol Endocrinol 2008, 22(5): III3-II 24

47. Creekmore AL, Walt KA Schultz-Norton JR, Ziegler YS, McLeod IX Yates JR, Nardulli AM: The role of retinoblastoma associated proteins 46 and 48 in estrogen receptor alpha mediated gene expression. Mol Cell Endocrinol 2008, 29I(I-2):79-86.

48. Landel CC, Kushner PJ, Greene GL: The interaction of human estrogen receptor with DNA is modulated by receptor-associated proteins. Mol Endocrinol 1994, 8:1407-1419.

49. Boonyaratanakornkit $\mathrm{V}$, Melvin $\mathrm{V}$, Prendergast $\mathrm{P}$, Altmann $M$, Ronfani L, Bianchi ME, Taraseviciene L, Nordeen SK, Allegretto EA, Edwards DP: High-mobility group chromatin proteins I and 2 functionally interact with steroid hormone receptors to enhance their DNA binding in vitro and transcriptional activity in mammalian cells. Mol Cell Biol 1998, 18(8):447|-4487.

50. Romine L, Wood J, Lamia L, Prendergast P, Edwards D, Nardulli A: The high mobility group protein I enhances binding of the estrogen receptor DNA binding domain to the estrogen response element. Mol Endocrinol 1998, 12:664-674.

5I. Vaesen M, Barnikol-Watanabe S, Gotz H, Awni LA, Cole T, Zimmerman B, Kratzin HD, Hilschmann N: Purification and characterization of two putative HLA class II associated proteins: PHAPI and PHAPII. Biol Chem Hoppe-Seyler 1994, 375: I I3-I 26. 
52. Beresford PJ, Kam CM, Powers JC, Lieberman J: Recombinant human granzyme A binds to two putative HLA-associated proteins and cleaves one of them. Proc Natl Acad Sci USA 1997, 94(I 7):9285-9290.

53. Seo SB, McNamara P, Heo S, Turner A, Lane WS, Chakravarti D: Regulation of histone acetylation and transcription by INHAT, a human cellular complex containing the set oncoprotein. Cell 2001, 104(1): I19-130.

54. Lieberman J, Fan Z: Nuclear war: the granzyme A-bomb. Curr Opin Immunol 2003, I 5(5):553-559.

55. Chowdhury D, Beresford PJ, Zhu P, Zhang D, Sung JS, Demple B, Perrino FW, Lieberman J: The exonuclease TREXI is in the SET complex and acts in concert with NM23-HI to degrade DNA during granzyme A-mediated cell death. Mol Cell 2006, 23(I): $133-142$.

56. Lindahl T, Sedgwick B, Sekiguchi M, Nakabeppu Y: Regulation and expression of the adaptive response to alkylating agents. Annu Rev Biochem 1988, 57:133-157.

57. Wood RD: DNA repair in eukaryotes. Annu Rev Biochem 1996, 65:135-167.

58. Tom S, Henricksen LA, Bambara RA: Mechanism whereby proliferating cell nuclear antigen stimulates flap endonuclease $I$. J Biol Chem 2000, 275( I 4): 10498-10505.

59. Beresford PJ, Zhang D, Oh DY, Fan Z, Greer EL, Russo ML, Jaju M, Lieberman J: Granzyme A activates an endoplasmic reticulum-associated caspase-independent nuclease to induce single-stranded DNA nicks. J Biol Chem 200I, 276(46):43285-43293.

60. Fan Z, Beresford PJ, Oh DY, Zhang D, Lieberman J: Tumor suppressor NM23-HI is a granzyme A-activated DNase during CTLmediated apoptosis, and the nucleosome assembly protein SET is its inhibitor. Cell 2003, I I 2(5):659-672.

61. Fan Z, Beresford PJ, Zhang D, Xu Z, Novina CD, Yoshida A, Pommier $Y$, Lieberman J: Cleaving the oxidative repair protein Ape I enhances cell death mediated by granzyme A. Nat Immunol 2003, 4(2): 145-153.

62. Melvin VS, Edwards DP: Coregulatory proteins in steroid hormone receptor action: the role of chromatin high mobility group proteins HMG-I and -2. Steroids 1999, 64(9):576-586.

63. Verrier CS, Roodi N, Yee CJ, Bailey R, Jensen RA, Bustin M, Parl FF: High-mobility group (HMG) protein HMG-I and TATAbinding protein-associated factor TAFII30 affect estrogen receptor-mediated transcriptional activation. Mol Endocrinol 1997, II:1009-1019.

64. Zhang CC, Krieg S, Shapiro DJ: HMG-I stimulates estrogen response element binding by estrogen receptor from stably transfected HeLa cells. Mol Endocrinol 1999, I3(4):632-643.

65. Aaltomaa S, Lipponen P, Syrjanen K: Proliferating cell nuclear antigen (PCNA) immunolabeling as a prognostic factor in axillary lymph node negative breast cancer. Anticancer Res 1993, I3(2):533-538.

66. Kim J, Petz LN, Ziegler YS, Wood JR, Potthoff SJ, Nardulli AM: Regulation of the estrogen-responsive pS2 gene in MCF-7 human breast cancer cells. I Steroid Biochem Mol Biol 2000, 74(4): $157-168$.

67. Sakurai S, Kitano K, Okada K, Hamada K, Morioka H, Hakoshima T: Preparation and crystallization of human flap endonuclease FEN-I in complex with proliferating-cell nuclear antigen, PCNA. Acta Crystallogr D Biol Crystallogr 2003, 59(Pt 5):933-935.

68. Dianova II, Bohr VA, Dianov GL: Interaction of human AP endonuclease I with flap endonuclease I and proliferating cell nuclear antigen involved in long-patch base excision repair. Biochemistry 200I, 40(42): 12639-12644.

69. Fan Z, Beresford PJ, Zhang D, Lieberman J: HMG2 interacts with the nucleosome assembly protein SET and is a target of the cytotoxic T-lymphocyte protease granzyme A. Mol Cell Biol 2002, 22(8):2810-2820.

70. Xia L, Zheng L, Lee HW, Bates SE, Federico L, Shen B, O'Connor TR Human 3-methyladenine-DNA glycosylase: effect of sequence context on excision, association with PCNA, and stimulation by AP endonuclease. I Mol Biol 2005, 346(5): $1259-1274$.

7I. Li X, Li J, Harrington J, Lieber MR, Burgers PM: Lagging strand DNA synthesis at the eukaryotic replication fork involves binding and stimulation of FEN-I by proliferating cell nuclear antigen. J Biol Chem 1995, 270(38):22 109-22 II 2.
72. Wu X, Li J, Li X, Hsieh CL, Burgers PM, Lieber MR: Processing of branched DNA intermediates by a complex of human FENI and PCNA. Nucleic Acids Res 1996, 24:2036-2043.

73. Hosfield DJ, Mol CD, Shen B, Tainer JA: Structure of the DNA repair and replication endonuclease and exonuclease FEN-I: coupling DNA and PCNA binding to FEN-I activity. Cell I998, 95: $135-146$.

74. Scharer OD, Jiricny J: Recent progress in the biology, chemistry and structural biology of DNA glycosylases. Bioessays 200I, 23:270-28I.

75. Das D, Peterson RC, Scovell WM: High mobility group B proteins facilitate strong estrogen receptor binding to classical and half-site estrogen response elements and relax binding selectivity. Mol Endocrinol 2004, 1 8:2616-2632.

76. Hong R, Chakravarti D: The human proliferating cell nuclear antigen regulates transcriptional coactivator $\mathrm{p} 300$ activity and promotes transcriptional repression. J Biol Chem 2003, 278:44505-445।3.

Publish with BioMed Central and every scientist can read your work free of charge

"BioMed Central will be the most significant development for disseminating the results of biomedical research in our lifetime. "

Sir Paul Nurse, Cancer Research UK

Your research papers will be:

- available free of charge to the entire biomedical community

- peer reviewed and published immediately upon acceptance

- cited in PubMed and archived on PubMed Central

- yours - you keep the copyright 